in point of birth, they ought to have an equal or greater rate of pay. Without injury to any section of the service, ample and cogent reason for placing us in the ward-room might be found in the extent of our education, and the absolute necessity of study to maintain that which we have toiled for years to acquire. There cannot be an insurmountable difficulty in point of cabin-room for us, as it is an indisputable fact, that if extra lientenants \&c. are appointed to ships, cabins are built without the least demur; and it is well known, that in most ships during their commission there are spare cabins, which are appropriated for the mess stores of the captain or lieutenants. If, however, any difficulty does exist, it cannot extend beyond brigs, which are much larger than they used to be; and if assistant-surgeons-in reality-could not be accommodated with cabins, they might still mess in the gunroom. There can be no lack of cabin room !

There is, I regret to state, one paltry and private reason of the naval authorities for keeping us in the midshipman's berth, but for which, I believe, we should lately have been made ward-room officers-it is, that we are required to superintend the general conduct of the youngsters, and to check the various excesses which are frequently committed on shipboard. But most assuredly a medical officer is not the proper person to be taxed with the care of young naval cadets and midshipmen. Why should the assistant-surgeon be harassed with such a charge, and deprived of his just position, whilst the naval instructor sits quietly in the ward-room? We do not wish to disturb the repose of the naval instructor, but in justice to ourselves, we must say the proper persons to superintend the conduct of the youngsters are the commissioned executive officers of the gun-room, the mates and second masters, one or more of whom should be in every commissioned ship. The care of the naval cadets and midshipmen, with whom we are quite unconnected, instead of being a substantial reason for detaining us in the midshipmen's berth, is a most potent argument against the removal of the mates, whatever their rank and claims may be. In the absence of the naval instructor, who should have charge of the youngsters but officers of their own profession?-

I am, Sir, your obedient servant, An Assistant-Surgeon R.N.

\section{LETTER TO THE SECRETARY OF THE LYING-IN INFIRMARY, BIRMINGHAM. To the Editor of THE LANCET.}

Sir,-I send the following, which is a copy of a letter I have just sent off per post, to Mr. D. Cope, Secretary to the Birmingham Lying-in Infirmary, and I leave it to you to print it, if so disposed, either with or without my name.

$$
\text { I am, Sir, your obedient servant, }
$$

Ieath-street, Hampstead, Middiesex.

S. GowEr. August 7 th, 1848 .

SIR,-Thanking you for your courtesy, I decline offering myself as a candidate for the office of resident surgeon to the Birmingham Lying-in Infirmary, because of the salary (which I understand from you to be $£ 30$ a year, besides board and lodging) being too low. You may add my compliments to the Board, and say that $I$ think that the resident surgeons for the time being ought to be set down in the list of contributors as subscribers of $£ 70$ per annum to the charity, at their present rate of salary. I have lately been instrumental in procuring a person a situation as footman, in a place in which he has his keep and $£ 40$ per annum. You may say also that Rule 24 is not civil enough for me. It is evident from the per centage of deaths in your annual report, that your resident medical officers have been humane, attentive, and skilful; much respon. sibility being attached to their office, were it only as to the discrimination they have to exercise in pronouncing upon such cases as appear to call for the advice of the consulting surgeons, a portion of their heavy responsibilities which must occasionally involve them in some embarrassment.

It is a pity that in place of their having a certain number of tickets to dispose of, out of consideration for the smallness of their salary, or their being given to understand that upon their extension of the benefits of the charity to any cases of urgency an act of indemnity would be freely passed by the board, they should be treated like common pickpockets by the Rule 24 referred to, which seems to insinuate, that however humane and skilful they may be, they are, unfortunately, (and this as a class of persons,) wanting in common honesty; as if it were not enough for men to sign an adherence to the rules, without stating that upon the violation of one especial one it is to be "upon pain of immediate dismissal"! Any. thing more unseemly it will be difficult to meet with any. where. Medical men-those with whom I have been acquainted-have been ever ready to promote every kindly and charitable public medical institution, to their own detriment; so much so, that they rather require the interference of the public to prevent them from injuring themselves than to urge them to further self-sacrifice. Added to this readiness, which is irrespective of other considerations, there has arisen much competition doubtless. Commencing in a spirit of disinterested benevolence on the part of medical practitioners, the habit of expecting them to work hard for little or nothing at length became established. This has ended in the governors of many of our institutions treating medical men like the dirt beneath their feet, as your Rule 24 treats your resident surgeons. But it does not follow that because medical men contest offices of little or no pay, that boards of directors should proceed accordingly upon the principle of " seething the kid in its mother's milk," and take advantage now of necessities as they at first availed themselves of volunteered skill and toil. It may be shown, for example, that persons or families never having received parish relief, have existed for a week or more upon two or three cold potatoes per diem; and it may be alleged, that for persons seeking relief within the walls of a workhouse, a diet not exceeding that of the starved man who is too independent to seek such relief onght to suffice. But no; the character of the country-of the locality-is at stake, and public fecling will not permit that a systematized starvation shall prevail, whatever may be the cases of incidental starvation in the world withontside the walls of the workhouse. So, whatever may be the condition of many medical practitioners not in public office, but in private practice for themselves, it has to be considered, not how little will be accepted, owing to competition, but what it is decent and becoming to allow-the necessary outlay and requisite exertion of the mental faculties, attendant on an efficient surgical and medical education, being borne in mind, and the amount of work set them to do being also considered. It is doubtful, moreover, whether their charity - which towards their two resident medical officers is very much akin to the "tender mercies of the wicked"-does one farthing's-worth of good per annum to the poor individually, or en masse, except in so far as their supply to them of culinary assistance is involved.

I write this, not doubting that there are men of sense and spirit connected with the board, who will overlook the rudeness out of respect for the truth of this communication. I am sure upon the general question that it is by no means a matter of sufficient observation how many medical men devote the morning and meridian of their days to hard work, done out of charity. If an established necessity enforces this, charity ceasing to have much to do with it, it is the more pitiable. It is a reflection upon society that such a state of things should exist. The payment of your resident medical officers is not a commonly honest transaction. It would be an excellent thing for poor people to be able to go to a baker's shop where they could get eightpenny loaves for fourpence. If charitable persons would make up to the baker, by subscription, the fourpence minus, he would be the better for it as well as his customers; but if only twopence of it be made up to him, he, out of his own pocket, gives individually towards the charity as much as the whole of the charitable persons give collectively. There may be some rich and benevolent bakers who agree to this; after awhile it comes to be expected that others who cannot afford it should either do it or be thought ill of. It terminates in extorting this concession from all; and the concession having become a customary and permanent thing, there seems to be no occasion to thank any one for doing what society forces him to do. Medical men have been, and are being, served in much the same way. It may be said and thought that they thus get introduced to practice; they do not as the rule, only as the exception: they are set down as poor men's doctors, and are nore commonly kept down in the world by it; not that they ought to be, but as if practice upon an extensive scale were not practice, and as if there were any difference between the anatomy and physiology of a duke and of a dustman. The barrister must starve or live upon his income till he gets briefs, and the medical man till he gets patients; but the case of the latter resembles that of the barrister who should be expected, during the first ten or fifteen years of such practice as he can meet with, to take no higher than half-crown fees; or the solicitor, during the same period, to charge eightpente instead of six-and-eightpence for advice. I met, in a steamboat, yesterday, with a genteellydressed man, who was telling another that he had had cholera and gone to a hospital for medicines. He said that he thought 
it would all come to that in the end-that is, that it would all come for every body to get advice and medicine gratuitously. Matters certainly so tend to this result that there appears need of either an act of parliament excluding from within the pale of the medical profession all men possessed of an independent income of less than $£ 300$ a year, or else an act making it " in England a misdemeanour, and in Scotland a crime and an offence," for any medical man to undertake any public office without being well paid for it.

I am. Sir, your obedient servant.

To Mr. David Cope, Secretary to the S. GowER, M.R.C.S.E., \&c. Lying-in Infirmary, Birmingham.

PROFESSIONAL QUACKERY AND ITS CAUSES.-A CONTRAST OF THE MEDICAL AND LEGAL PROFESSIONS.

\section{To the Editor of The Lavcer.}

SrR,-As long as we have such things as Lambeth Beck's Specific Mixture, and Liverpool Taylor's College for the Cure of Cancer; as long as we have men like the Upton-on-Severn applicants, who prove traitorous to the true dignity and welfare of th+ir profession, Mr. O'Shea has every right to designate such doings as " the gross blackguardism that is practised in the profession," and the public has every right to reiterate his ha! ha! ha!

How is it, Mr. Editor, that the profession of medicine in this country teems with men who descend to the most corrupt practices? How is it that it can so ill bear to be contrasted with its sister profession, the law? One would reasonably expect, that the profession of medicine, having nobler ends to secure than the legal profession, would possess a fuller measure of public esteem and respect. Yet contrast the twocan there be a doubt which profession is freer from abnses, which derives more honour from the respectability of its members.

I think, Mr. Editor, the remote cause of this rottenness may be traced to the introduction of men into the ranks whose early education and position in life has not been such as to fit them for the liberal exercise of a profession. The more immediate cause, is the necessity of living, urging such men to pursue a line of conduct which, though unbecoming and strictly unprofessional, is entered upon without reserve.

The law, in her wisdom, has prevented the influx of men into her ranks, who, from education and position in life, were not likely to uphold the interests of the profession by a liberal practice.

To this end, the stamp duty and fee amount to such a sum, that no parent who is not himself in a position which would guarantee a good education to his children, could afford to place a son in the law. The consequence is, that members of the legal profession are drafted from families whose position in life ensures to their children that sort of education and those advantages which accrue from a uniform class-appreciation of what is becoming and correct.

The facility with which a young man can gain admittance into the medical profession has opened the door to the ambition of many a petty tradesman, who fancies that, by putting his son into a profession, he can "make a gentleman" of him. He is just able to pay the first expense-the apprenticeship; the young man (who has never associated with educated people, and cannot be expected to have the ideas and feelings which bclong to this class) passes through a term of five years in a sort of servant-like drudgery, which is calculated to lower rather than to elevate his inind. The period arrives when he ought to enter the schools, and his friends then learn, that the expense of walking the hospitals, as it is called, will be quite as much, if not more than they can compass; at all events, the youth is told that from the very day he obtains his diploma he must gain his own bread. What follows? He finds that men in the professions of law and medicine must pass through a state of probation, which may extend over weeks, and months, and possibly over years. His object is to cut this term short. Does he manifest any reluetance to engage in pursuits unbecoming a professional man, or likely to reflect on the profession of which he has become a member? Assuredly not! to him such feelings are foreign; he cannot understand them; his sole object is to obtain a living, and all means are expedient to this end which are not actually unlawful.

This is a true picture of the career of hundreds of members of the profession of medicine in this country. How little could such men enter into the spirit of the following, from the pen of Lord Bacon:-" I hold every man a debtor to his profession, from which, as men of course do seek to receive countenance and profit, so ought they, of daty, to endeavour themselves, by way of amends, to be a help and ornament thereunto. This is performed, in some degree, by the honest and liberal practice of a profession, when men shall carry a respect not to descend into any course which is corrupt and unworthy thereof, and preserve themselves free from the abuses wherewith the same profession is noted to be infected."

In 55 Geo. III. cap. 184, we find:- " The sum of money, or the value paid with or in respect of an apprentice, shall, if the amount be under $£ 30$, be $£ 1$; if above $£ 30$ and under $£ 50$, $£ 2$; if above $£ 50$ and under $£ 100, £ 3$; if above $£ 100$ and under $£ 200, £ 6 . "-$ N.B. $£ 50$ is a very common apprenticeship fee.

The first admission to the legal profession stands thus:"Articles of clerkship, whereby a person shall first become bound as a clerk, in order to his admission as an attorney or solicitor, stamp-duty £120, for any of her Majesty's courts of Westminster." - 55 Geo. III. cap. 184.

In addition to this sum, no respectable office in the country receives a less fee than $£ 200$ with such clerk, and the fee generally given is $£ 300$. The attorney, moreover, pays to the crown, during the first four years of practice, $£ 4$ per annum for his certificate; and he afterwards pays $£ 8$ per annum, so long as he continues to practise his profession.

I hope, Mr. Editor, you will use the great influence you possess in endeavouring to alter the present mode by which a man enters the profession; the apprenticeship system has been a great curse; I trust it may be done away with altogether; and that medical education may be extended over a term requiring a residence of full five years; no youth being allowed to matriculate before the age of nineteen. I am, Sir, your obliged servant,

August 9th, 1848

Filios Machaonis.

\section{fftedical $\$$ Hefns.}

A pothecaries' Hall.-Names of gentlemen who passed their examination in the science and practice of medicine and received certificates to practise, on Thursday, 24 th Angust, 1848:-William John Player, Swansea; William Richard Hilton, Whitehaven, Cumberland.

Medical Matters in the United States.-At a late meeting of the onnecticut Medical Society, a resolution to the following effect was laid on the table for consideration:"That, as it has been customary to render medical services to clergymen and their families gratuitously, and as it is believed that, as a class, their education, intelligence, and moral standing considered, they do more than any other class to embarrass the legitimate influence of the medical protession; theretore, resolved, that we adopt the practice of charg. ing clergymen the same fees as other citizens, except in cases of misfortune and inability."-The New York Thompsonian, the only paper advocating the pretensions of that humbug (homœopathic) sect, has been discontinued, and the editor states that the sect was never before at so low an ebb as at present. He thinks, however, that there is still vitality enough " to put on the steam of everlasting truth" and "set in motion again the car of medical reform."-The State of Pennsylvania has authorized the Homœopathic College in Pennsylvania to grant diplomas.-The Boston Medical Journal says that a galvanic ring mania is quite epidemic in New England. They not only cover their fingers and necks with them, but their toes are not exempted from their application. - (Quoted in the Dublin Medical Press.)

SuRgery in British Indra.-The published reports of the Government Charitable Dispensaries exhibits the following catalogue of severe surgical operations performed by Native sub-assistant surgeons, with their results:-

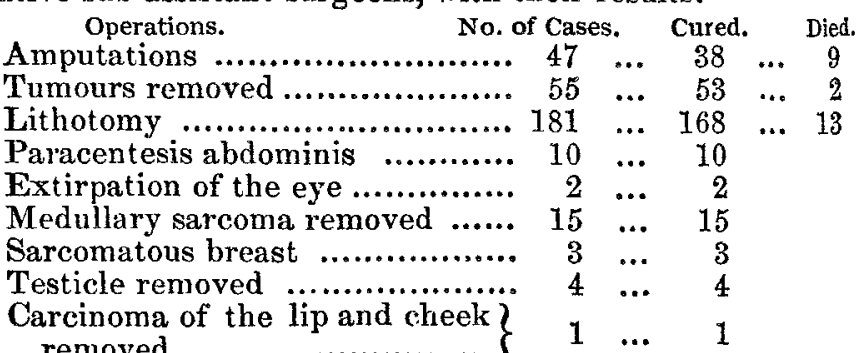

This is independent of a multitude of minor operations, and thousands of succerssful medical cases, embracing the most formidable endemic and epidemic diseases of the country as well as in the private practice of the passed students settled 